\title{
Pengaruh Online Customer Review dan Rating Terhadap Kepercayaan dan Minat Pembelian pada Online Marketplace di Indonesia
}

\author{
Ahmad Farki, Imam Baihaqi, dan Berto Mulia Wibawa. \\ Jurusan Manajemen Bisnis, Fakultas Teknologi Industri, Institut Teknologi Sepuluh Nopember (ITS) \\ Jl. Arief Rahman Hakim, Surabaya 60111 Indonesia \\ e-mail: ibaihaqi@mb.its.ac.id
}

\begin{abstract}
Abstrak-Perkembangan teknologi telah membuat pergeseran perilaku berbelanja pelanggan dari offline ke online di seluruh dunia termasuk Indonesia, salah satunya ditandai dengan pertumbuhan e-commerce di seluruh dunia yang sedang mengalami peningkatan yang signifikan. Salah satu fitur yang terdapat pada online shop, Online Customer Review (OCR) barubaru ini mendapat perhatian yang cukup besar, baik dalam komunitas akademis maupun bisnis pada hubungannya dengan minat pembelian pelanggan. OCR dianggap merupakan salah satu faktor yang cukup penting dalam memengaruhi kepercayaan maupun minat pembelian pelanggan. Penelitian sebelumnya membuktikan bahwa OCR memiliki pengaruh terhadap minat pembelian pelanggan di online shop. Penelitian ini bertujuan untuk mengetahui dampak OCR pada online marketplace di Indonesia dengan menambahkan variabel baru yaitu rating. Penelitian ini menggunakan metode Structural Equation Modelling (SEM) dengan 313 responden dikumpulkan dari pengguna internet yang pernah berbelanja di online marketplace. Hasil yang didapat dari penelitian ini adalah OCR baik review maupun rating terbukti memiliki hubungan terhadap minat pembelian pelanggan dan menjadi salah satu fitur yang penting, namun bukan faktor yang menyebabkan meningkatnya kepercayaan pelanggan. Oleh karena itu perusahaan online marketplace harus menjadikan review dan rating sebagai salah satu tools marketing utama yang dapat meningkatkan pendapatan perusahaan.
\end{abstract}

Kata Kunci-E-Commerce, Kepercayaan, Minat Pembelian, Online marketplace, Review, Rating

\section{PENDAHULUAN}

$\mathrm{P}$ ERKEMBANGAN teknologi telah membuat pergeseran perilaku pelanggan dari pembelian melalui offline shop menjadi pembelian melalui online shop atau melalui $e$ commerce. Perubahan tersebut memengaruhi keputusan pembelian konsumen dalam membeli suatu produk. Hal tersebut banyak dipengaruhi oleh persepsi mereka terhadap harga, produk, promosi, tempat (bauran pemasaran) yang telah diterapkan oleh perusahaan selama ini [1]. Untuk memahami bagaimana konsumen benar-benar membuat keputusan pembelian, pemasar harus mengidentifikasi siapa yang mengambil keputusan dan mempunyai masukan dalam keputusan pembelian [1].

Mudahnya berbelanja di online shop adalah salah satu alasan perubahan perilaku pelanggan ini terjadi. Hal itu juga didukung dari data nilai transaksi e-commerce di seluruh dunia dan khususnya di Indonesia yang terus meningkat tiap tahunnya. Hal ini membuat penelitian tentang e-commerce di dunia saat ini menjadi topik yang menarik untuk diteliti. Meningkatnya pertumbuhan e-commerce di Indonesia ini juga didukung oleh pemerintah yang berjanji untuk mendukung pertumbuhan dengan pembangunan logistik, infrastruktur, financing institution dan aspek pendukung lainnya secara berkelanjutan.

Alasan utama dari pergeseran perilaku dari offline ke online ini adalah didasarkan pada kemudahan yang ditawarkan oleh online shop, namun selain kemudahan yang didapat, banyak juga faktor-faktor yang menyebabkan pelanggan untuk tidak menggunakan e-commerce, yaitu masalah resiko, yang umumnya terkait seputar keamanan dalam pembayaran, ketakutan akan penipuan, ataupun kualitas barang yang tidak sesuai ekspektasi. Kepercayaan dan juga resiko adalah faktor yang memengaruhi keputusan pembelian [2]-[3] dan juga pembelian kembali [4] pada transaksi online.

Perbedaan utama antara online shop dan offline shop adalah kemampuan pelanggan untuk menilai suatu produk sehingga dapat menimbulkan keinginan hingga keputusan pembelian. Pada online shop calon pembeli tidak dapat memeriksa barang yang mereka ingin beli secara langsung dan biasanya hanya dibantu oleh gambar ataupun deskripsi yang diberikan oleh penjual, sedangkan pada offline shop kita dapat melihat maupun menyentuh barang secara fisik. Selain itu pada online shop proses pembayaran juga menjadi kendala karena kebanyakan online shop mengharuskan kita mentransfer sejumlah dana terlebih dahulu sebelum barang dapat diantar ke rumah. Untuk itu tentu perlu adanya kepercayaan yang tinggi kepada online shop agar kita berani untuk melakukan pembayaran dengan cara seperti tersebut. cara pembayaran lain biasanya adalah dengan menggunakan kartu kredit, sedangkan pada offline shop kita bisa langsung membayar dengan uang cash.

Berdasarkan masalah-masalah tersebut banyak strategi pemasaran pada online shop yang mungkin dapat menjadi pertimbangan utama bagi konsumen maupun calon konsumen untuk bertransaksi secara online. Di antara banyaknya fitur pada online shop, Online Customer Review (OCR) atau juga 
bisa disebut sebagai electronic word of mouth (eWOM) adalah salah satu fitur yang telah menarik banyak perhatian dari akademisi maupun masyarakat sebagai salah satu faktor yang paling berpengaruh dalam menentukan keputusan pembelian pada konsumen [5]-[6]. Online Customer Review adalah sebuah bentuk electronic word of mouth (eWOM) yang mengacu pada konten buatan pengguna yang di-posting pada situs online maupun situs web pihak ketiga [7].

Saat ini di Indonesia sendiri tren online shop atau juga online marketplace sedang naik. Mulai banyak bermunculan online shop baru menambah daftar online shop lama yang sudah lebih dulu berkecimpung di bisnis e-commerce ini. Sebut saja Lazada, Tokopedia, Rakuten, Zalora, Mataharimall, dan lain lain. Online marketplace tersebut tidak hanya dimiliki oleh perusahaan asal Indonesia saja namun juga Korea (Elevenia), Jepang (Rakuten), dan lain lain. Bila pada online shop dianggap satu toko yang berjualan, pada online marketplace ada banyak toko yang berjualan. Hal ini menegaskan bahwa perilaku pelanggan sudah mulai berubah dan banyak perusahaan yang sudah melihat akan peluang dari bisnis $e$ commerce tersebut.

Meningkatnya e-commerce di Indonesia membuat penelitian tentang OCR ini penting untuk dilakukan. Hal itu untuk mendukung agar customer dapat memiliki pengalaman belanja online yang lebih baik daripada belanja offline. Dengan mengetahui faktor yang memengaruhi keputusan pembelian dari pelanggan, perusahaan maupun pebisnis dapat mendapatkan pengetahuan yang penting untuk menerapkan strategi pemasaran yang lebih baik khususnya pada media online. Namun tidak menutup kemungkinan bahwa OCR bukan satu-satunya fitur paling penting yang menentukan keputusan pembelian pada pelanggan. Penelitian ini bertujuan untuk mengetahui hubungan antara OCR terhadap kepercayaan maupun minat pembelian pada online marketplace di Indonesia. Dengan adanya penelitian ini diharapkan peneliti dapat memberi gambaran tentang bagaimana perilaku pelanggan online saat ini dan dapat digunakan untuk menentukan strategi pada online marketplace dari temuan yang didapat pada penelitian ini.

\section{URAIAN PENELITIAN}

\section{A. E-Commerce}

E-commerce adalah tentang menjual online atau kemampuan untuk bertransaksi secara online. Ini termasuk ritel, perbankan online dan belanja - yang melibatkan transaksi dimana pembeli benar-benar membeli dan berbelanja [8]. Beberapa alasan kenapa orang-orang mulai berpindah dari berbelanja offline ke online adalah karena alasan kemudahan yang diberikan oleh berbelanja online. Meningkatnya $e$-commerce juga berpengaruh terhadap konsep online shop itu sendiri yang terus berkembang. Online marketplace, salah satu konsep dari online shop dimana terdapat banyak penjual yang berjualan disana sebenarnya sudah didefinisikan sejak dulu.

Menurut [9] e-marketplace didefinisikan sebagai sebuah sistem informasi antar-organisasi yang memungkinkan pembeli dan pemasok berpartisipasi untuk bertukar informasi tentang harga dan produk yang ditawarkan. Perusahaan yang mengoperasikan sistem disebut sebagai perantara dimana pelaku pasar adalah pembeli dan penjual, pihak ketiga yang independen, atau konsorsium perusahaan-perusahaan. salah satu fitur utama yang ada pada online marketplace saat ini adalah penggunaan review dan rating sebagai tools untuk meningkatkan minat maupun kepercayaan pelanggan

\section{B. Online Customer Review}

Review merupakan bagian dari Electronic Word of Mouth (eWOM), yaitu merupakan pendapat langsung dari seseorang dan bukan sebuah iklan. Review adalah salah satu dari beberapa faktor yang menentukan keputusan pembelian seseorang [10], menunjukkan bahwa orang dapat mengambil jumlah review sebagai indikator popularitas produk atau nilai dari suatu produk yang akan mempengaruhi kemauan untuk membeli suatu produk. Namun belum tentu semakin banyak review dan rating berarti produk tersebut pasti akan dibeli oleh pelanggan. Banyak faktor-faktor yang menjadi alasan keputusan pembelian suatu produk bagi pelanggan.

Online review dapat menjadi alat promosi yang ampuh untuk komunikasi pemasaran. Pemasar dan vendor telah menggunakan media ini karena memberikan saluran yang murah dan berdampak untuk menjangkau pelanggan mereka. Pemasar diketahui telah mengambil keuntungan dari jaringan pengaruh antara pelanggan untuk mempengaruhi perilaku pembelian pembeli potensial.

\section{Online Customer Rating}

Rating adalah bagian dari review yang menggunakan bentuk simbol bintang daripada bentuk teks dalam mengekspresikan pendapat dari pelanggan. Rating dapat diartikan sebagai penilaian dari pengguna pada preferensi suatu produk terhadap pengalaman mereka mengacu pada keadaan psikologis dan emosional yang mereka jalani saat berinteraksi dengan produk virtual dalam lingkungan dimediasi [11].

Moe dan Schweidel, (2012) [12] menghubungkan antara rating terhadap tingkat pengambilan keputusan pelanggan. Mereka menemukan bahwa pengaruh penilaian pelanggan terhadap rating sebelum memutuskan membeli sesuatu tergantung pada seberapa sering rating atau penilaian dilakukan oleh pelanggan ini pada suatu produk.

\section{Technology Acceptance Model (TAM)}

Dalam meneliti hubungan review dan rating pada kepercayaan dan minat pembelian pelanggan pada penelitian ini, digunakan model TAM yang biasa digunakan untuk menguji penerimaan teknologi baru. Technology Acceptance Model (TAM) yang dikembangkan oleh Davis (1989) [13] adalah salah satu model penelitian yang paling populer untuk memprediksi penggunaan dan penerimaan sistem informasi dan teknologi oleh pengguna individu. TAM merupakan model yang dikembangkan untuk mempelajari penerimaan teknologi oleh individu yang menjelaskan bagaimana individu dapat 
menerima dan menggunakan teknologi, berasal dari teori tindakan beralasan. Hal ini banyak digunakan untuk menjelaskan adopsi teknologi baru, didukung oleh dua konstruksi: "perceived usefulness" dan "perceived ease of use" [14].

\section{E. Theory of Planned Behaviour (TPB)}

TPB dikembangkan oleh Ajzen (1988) [15] menghubungkan kepercayaan dengan perilaku untuk meningkatkan kekuatan prediksi dari teori tindakan beralasan dengan penyertaan perceived control. TPB dibangun berdasarkan oleh sikap, norma subjektif, dan perceived behavioural control, untuk memprediksi perilaku yang disengaja, karena perilaku dapat direncanakan [16]. Berdasarkan TPB, keinginan hanya dapat disampaikan pada perilaku sebenarnya jika perilaku tersebut berada di bawah perceived control dari individu [17]. TPB digunakan untuk mengukur tingkat kontrol yang diberikan oleh review maupun rating yang kemudian membantu melihat hubungannya dengan kepercayaan dan minat pembelian.

\section{METODOLOGI PENELITIAN}

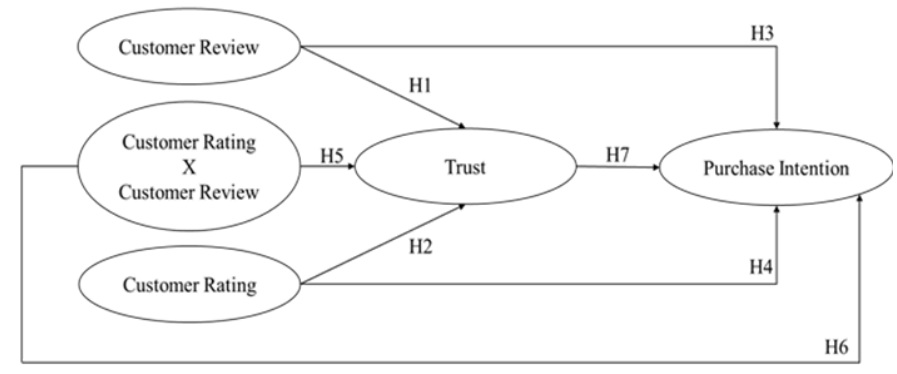

Gambar. 1. Kerangka Penelitian

\section{A. Kerangka Penelitian}

Penelitian ini menggunakan model TAM maupun TPB dalam menjelaskan atribut dari review dan rating yaitu perceived usefulness, perceived enjoyment, dan juga perceived control. Ketiga atribut tersebut menjelaskan review maupun rating dari tingkat kebermanfaatannya, tingkat kenyamanan dalam menggunakan, maupun tingkat seberapa kuat review dan rating dapat mendorong keinginan kita akibat menggunakannya. Dari 3 variabel tersebut kemudian menjadi sebuah variabel laten yang disebut sebagai review dan juga rating. Selain mengetahui hubungan review dan rating terhadap kepercayaan maupun minat pembelian pelanggan, peneliti juga ingin mengetahui hubungan interaksi keduanya sehingga kemudian di buat sebuah variabel baru yang disebut dengan review_x_rating. Dari semua variabel tersebut membentuk sebuah kerangka penelitian utuh yang dapat dilihat pada Gambar 1. Dari kerangka penelitian tersebut didapat 7 hipotesis penelitian yaitu H1: Customer review pada online marketplace berpengaruh positif terhadap trust pelanggan. H2: Customer rating pada online marketplace berpengaruh positif terhadap trust pelanggan. H3: Customer review pada online marketplace berpengaruh positif terhadap purchase intention pelanggan. H4: Customer rating pada online marketplace berpengaruh positif terhadap purchase intention pelanggan. H5: Interaksi antara customer review dan customer rating berpengaruh positif terhadap trust pelanggan. H6: Interaksi antara customer review dan customer rating berpengaruh positif terhadap purchase intention pelanggan. H7: Trust berpengaruh positif terhadap purchase intention pelanggan.

\section{B. Desain Penelitian}

Metode penelitian yang digunakan pada penelitian ini adalah metode conclusive design. Conclusive design merupakan penelitian yang menjelaskan hubungan kausal antara variabelvariabel melalui pengujian hipotesis [18]. Tujuan dari conclusive design adalah untuk menggambarkan suatu fenomena tertentu, menguji hipotesis tertentu, dan untuk menguji suatu hubungan [19]. Penelitian ini adalah penelitian descriptive research dengan single cross-sectional, yaitu penelitian yang tujuannya untuk mengetahui hubungan antara variabel penelitian, kemudian tahapan perolehan data pada penelitian ini dilakukan dalam satu periode dan hanya satu sampel responden diambil dari populasi sasaran, dan informasi diperoleh dari sampel hanya sekali [19].

Data yang diambil pada penelitian ini adalah data primer dengan menggunakan kuesioner. Pertanyaan pada kuesioner dibagi 3 yaitu mengenai profil responden, informasi perilaku responden, dan terakhir pertanyaan inti dengan menggunakan skala likert 7. Profil responden berisi mengenai informasi umur, jenis kelamin, tempat tinggal, pendidikan, pekerjaan, dan pendapatan. Informasi perilaku responden berisi mengenai beberapa pertanyaan terkait perilaku responden seperti frekuensi berbelanja dan lain-lain. Pertanyaan inti berisi pertanyaan mengenai variabel pada penelitian yaitu perceived usefulness, perceived enjoyment, perceived control, trust, dan purchase intention.

Pertanyaan pada variabel perceived usefulness diadopsi dari Gefen et al. (2003) and Koufaris (2002), perceived enjoyment diadopsi dari Van Dolen et al. (2007), perceived control diadopsi dari Van Dolen et al. (2007), trust dimodifikasi dari Lee and Turban (2001), dan purchase intention dari Zhang (1996) and Lee et al. (2012) dalam penelitian [14].

\section{Sampel}

Data dikumpulkan dengan penyebaran kuesioner berbasis online dengan menggunakan google form. Kriteria responden pada penelitian ini adalah pengguna internet di Indonesia yang pernah berbelanja khususnya di online marketplace. Dari penyebaran kuesioner selama 6 hari didapat responden sejumlah 313 data.

\section{Metode Analisis Data}

Pengolahan data pada penelitian ini menggunakan metode Structural Equation Modeling (SEM). Untuk uji asumsi klasik yang digunakan pada penelitian ini adalah analisis deskriptif, uji missing data dan outlier, uji normalitas, uji linearitas, uji homoskedastisitas, uji validitas dan reliabilitas, uji multikolinearitas dan uji hipotesis menggunakan SEM. 


\section{HASIL ANALISIS DATA DAN DISKUSI}

\section{A. Profil Responden}

Dari 313 data yang diperoleh selama 6 hari didapat informasi bahwa 59,1\% responden adalah perempuan dan 40,9\% responden adalah laki-laki. Kategori umur didominasi oleh responden remaja akhir atau yang berumur antara 17-25 tahun yaitu sebesar $62,6 \%$. Daerah tempat tinggal didominasi oleh responden yang berasal dari pulau jawa yaitu sebesar $60 \%$. Pekerjaan didominasi oleh pelajar dan mahasiswa $(51,1 \%)$ dengan mayoritas pendapatan keseluruhan responden masih dibawah Rp 2.000.000,00 per bulan (39,9\%).

\section{B. Analisis Data}

Dari 313 data yang diperoleh tidak ditemukan adanya missing data, namun dari data tersebut terdapat beberapa data outlier yang harus dikeluarkan dari penelitian sehingga tersisa 290 data yang akan dianalisis. Dari uji normalitas dengan melihat nilai skewness (kemiringan), kurtosis (keruncingan) dan menggunakan grafik Q-Q plots pada SPSS 22.0 didapat bahwa data penelitian ini normal. Nilai skewness harus kurang dari 2, dan nilai kurtosis tidak lebih dari 5 dapat dikategorikan sebagai data yang normal. Titik pada Q-Q plot pun berada di sekitaran garis normal

Linearitas diuji dengan menggunakan scatter plot dari variabel penelitian (Hair et al., 2014) ${ }^{[20]}$ yang menunjukkan adanya hubungan atau korelasi antar hubungan variabel yang terlibat dalam analisis SEM. Dari hasil pengujian ditemukan bahwa terdapat hubungan linearitas antar variabel dilihat dari persebaran titik pada scatter plot yang menyebar dan tidak membentuk pola tertentu.

Uji homoskedastisitas menunjukkan bahwa tidak terdapat heteroskedastisitas pada data penelitian ini. Pendeteksian dilakukan dengan menggunakan scatterplot antara nilai ZPRED (nilai prediksi) pada sumbu $\mathrm{X}$ dan SRESID (nilai residual) pada sumbu $\mathrm{Y}$. hasilnya tidak terdapat heteroskedastisitas dilihat dari data yang menyebar secara merata di atas dan dibawah angka nol sumbu Y. Hal ini menunjukkan bahwa model regresi telah memenuhi syarat homoskedastisitas.

Cronbach's alpha digunakan untuk menguji reliabilitas data pada penelitian ini. Hasilnya data telah memenuhi syarat reliabilitas dengan nilai cronbach's alpha telah melewati nilai batas minimum yaitu diatas 0,60 [21].

\section{Validitas Model}

Confirmatory Factor Analysis (CFA) digunakan untuk menguji validitas dari indikator penelitian terhadap variabelnya. Uji validitas dilakukan untuk melihat apakah alat ukur yang digunakan dapat merepresentasikan dengan tepat variabelvariabel yang diteliti. Data akan dianggap valid apabila nilai loading factor telah melewati batas minimum yaitu diatas 0,50 [20]. Hasil dari uji validitas model adalah semua variabel telah lulus uji validitas dengan nilai loading factor diatas 0,60 seperti yang dapat dilihat pada Gambar 2. Untuk variabel komposit juga lulus uji validitas dengan nilai loading factor diatas 0,80 .

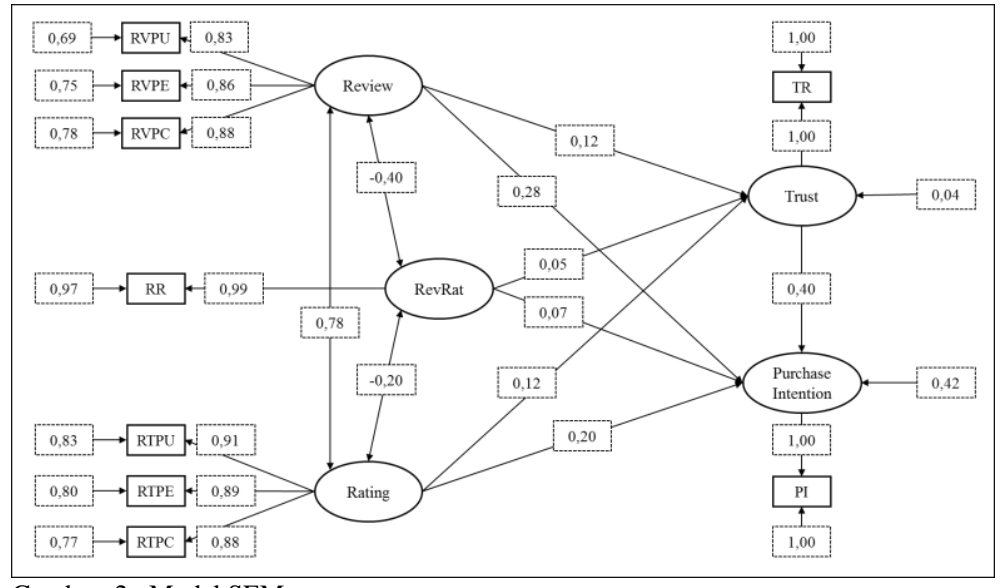

Gambar. 2. Model SEM

\section{Model Fit dan Uji Hipotesis}

Dari Tabel 1 terlihat bahwa nilai sebesar 0,932, CFI sebesar 0,951, dan RMR sebesar 0,038. Dari nilai tersebut didapatkan kesimpulan bahwa model SEM secara keseluruhan telah fit dilihat dari nilai goodness-of-fit nya yang sudah sangat bagus yaitu GFI $>0,90$ CFI $>0,95$ dan $\mathrm{RMR}<0,05$.

Tabel 1.

Goodness of Fit Index

\begin{tabular}{llll}
\hline \multicolumn{1}{c}{ Kriteria } & \multicolumn{1}{c}{ Hasil } & Nilai Kritis & Keterangan \\
\hline $\begin{array}{l}\text { Absolute Fit Indices } \\
\text { Goodness of Fit }\end{array}$ & & \\
GFI & 0,932 & $\geq 0,90$ & Fit \\
AGFI & 0,848 & $\geq 0,90$ & Marginal \\
Badness of Fit & & & \\
RMSEA & 0,119 & $\leq 0,08$ & Marginal \\
Incremental Fit Indices & & & \\
CFI & 0,951 & $\geq 0,95$ & Fit \\
NFI & 0,940 & $\geq 0,90$ & Fit \\
RMR & 0,038 & $<0,05$ & Fit \\
PRATIO & 0,556 & $\geq 0,60$ & Marginal \\
\hline \hline
\end{tabular}

Hasil dari uji hipotesis ada tabel 2. Menunjukkan bahwa hanya hipotesis 3,4 , dan 7 saja yang diterima dan sisanya ditolak, dilihat dari nilai signifikansi atau $p$-value yang berada diatas 0,05 atau berarti tidak signifikan. Semua hubungan terbukti memiliki nilai positif dengan tidak adanya nilai negatif pada nilai estimate meskipun hanya 3 hubungan yang terbukti signifikan.

Tabel 2.

Hasil Uji Hipotesis

\begin{tabular}{|c|c|c|c|c|c|}
\hline Faktor & & Faktor & Estimate & $\begin{array}{c}\mathrm{p}- \\
\text { value }\end{array}$ & Keterangan \\
\hline Review & $-->$ & Trust & 0,116 & 0,340 & Ditolak \\
\hline Rating & $-->$ & Trust & 0,117 & 0,294 & Ditolak \\
\hline Review & $-->$ & $\begin{array}{c}\text { Purchase } \\
\text { intention }\end{array}$ & 0,280 & 0,004 & Diterima \\
\hline Rating & $-->$ & $\begin{array}{c}\text { Purchase } \\
\text { intention }\end{array}$ & 0,204 & 0,020 & Diterima \\
\hline RevRat & $-->$ & Trust & 0,048 & 0,479 & Ditolak \\
\hline RevRat & $-->$ & $\begin{array}{c}\text { Purchase } \\
\text { intention }\end{array}$ & 0,074 & 0,161 & Ditolak \\
\hline Trust & $-->$ & $\begin{array}{l}\text { Purchase } \\
\text { intention }\end{array}$ & 0,397 & 0,000 & Diterima \\
\hline
\end{tabular}




\section{E. Diskusi}

Variabel review dan juga rating terbukti tidak memiliki hubungan terhadap kepercayaan pada online marketplace di Indonesia diduga disebabkan oleh karena kepercayaan pada online marketplace ternyata bukan disebabkan oleh review dan rating melainkan faktor lain. Hal ini diduga karena online marketplace merupakan perusahaan yang berskala besar sehingga sudah dipercaya pelanggan, apalagi beberapa online marketplace memiliki garansi apabila berbelanja disana. Selain itu online marketplace sudah memakai fasilitas rekening bersama yang secara tidak langsung mengurangi rasa tidak percaya yang dimiliki oleh pelanggan.

Variabel review dan rating terbukti memiliki hubungan yang signifikan terhadap minat pembelian pelanggan pada online marketplace di Indonesia. Menurut [22] review berbasis text (review) memiliki pengaruh yang lebih besar daripada review berbasis rating (rating). Hal ini juga dibuktikan pada penelitian ini dimana nilai signifikansi untuk review terhadap purchase intention lebih rendah daripada rating terhadap purchase intention yang berarti lebih signifikan. Sebagai sumber informasi langsung utama terhadap barang yang akan dibeli, review dan rating dari pelanggan dapat memberikan penilaian yang lebih bersifat akurat dan juga emosional karena diberikan oleh sesama pelanggan sehingga memiliki nilai kepercayaan yang lebih tinggi.

Hubungan interaksi antara review dan rating terbukti tidak memiliki hubungan yang signifikan terhadap trust maupun purchase intention. Menurut [22] hal ini disebabkan oleh kepercayaan dapat terhambat karena inkonsistensi jawaban seperti review yang memiliki teks negatif dengan nilai rating positif. Adanya jawaban yang berbeda seperti rating bagus namun review buruk dan sebaliknya dapat membuat orang lain bingung.

Terakhir trust terbukti memiliki pengaruh yang signifikan terhadap purchase intention sama seperti hasil penelitianpenelitian terdahulu yang pernah dilakukan.

\section{F. Implikasi Manajerial}

Berdasarkan analisis yang telah dilakukan didapat hasil bahwa dari sekian banyak responden, ternyata sebagian besar pernah memberikan review maupun rating pada online marketplace namun frekuensi pemberiannya masih tergolong rendah, oleh karena itu online marketplace harus mempertimbangkan untuk meningkatkan frekuensi pelanggan untuk memberikan review maupun rating caranya dengan mewajibkan pemberian review maupun rating atau dengan cara pemberian reward kepada mereka yang memberikan review dan rating

Karena didapatkan hasil review dan rating berpengaruh terhadap minat pembelian, mengindikasikan bahwa review dan rating sebaiknya digunakan sebagai pembanding dalam menentukan pembelian pada online marketplace oleh karena itu perlu dilakukan peningkatan kredibilitas dari review dan juga rating. Caranya adalah dengan memberikan penilaian atau merating review dan juga rating yang juga diterapkan di amazon.com selain itu dapat juga dengan pemberian profil orang yang memberikan review maupun rating, apakah mereka adalah orang yang pernah membeli, atau hanya yang tertarik saja, ataupun akun guest. Selain itu online marketplace juga perlu menerapkan aturan yang mencegah adanya akun dummy ataupun akun penjual yang memberikan review dan juga rating pada produk mereka sendiri untuk lebih meningkatkan kredibilitas.

Dilihat dari besarnya pengaruh dari review dan rating ini, sebaiknya perusahaan juga mempertimbangkan untuk menggunakan review dan rating tidak hanya pada produk saja namun juga pada hampir semua aspek yang berhubungan dengan pelanggan. Contohnya online chat, customer service, dan lain-lain.

Terakhir meskipun review dan rating tidak berpengaruh terhadap trust, namun trust masih memiliki pengaruh terhadap purchase intention, untuk itu online marketplace perlu untuk meningkatkan trust mereka di mata pelanggan. Cara yang paling utama untuk dilakukan adalah dengan meningkatkan trust pada penjual yang berjualan disana, karena akumulasi dari review dan rating terhadap penjual disana sama dengan trust pada online marketplace tersebut secara keseluruhan. Langkah yang dapat diambil adalah dengan menyaring siapa saja yang dapat berjualan disana sehingga benar-benar penjual yang kredibel saja yang dapat berjualan disana. Selain itu pemberian review dan rating terhadap penjual juga perlu dilakukan, yang terakhir adalah dengan pemberian informasi yang menyeluruh terkait dengan penjual yang berada di online marketplace. Informasi tersebut dapat berupa kapan terakhir mereka login, berapa barang yang pernah mereka jual, dimana alamat penjual, nomor yang bisa dihubungi, dan lain-lain yang sekiranya dapat membuat orang lebih percaya.

\section{KESIMPULAN/RINGKASAN}

Dari penelitian yang telah dilakukan ditemukan bahwa mayoritas responden adalah kalangan pelajar dengan rentang umur 17-25 tahun dan berpenghasilan tergolong rendah. Mayoritas responden juga masih berasal dari pulau jawa. Hal ini dapat diartikan bahwa responden yang menggunakan internet kebanyakan dari kalangan anak muda dan pulau jawa.

Dari uji hipotesis yang dilakukan, ternyata dari ke 7 hipotesis hanya 3 yang dapat diterima yaitu review dan rating terhadap minat pembelian dan kepercayaan terhadap minat pembelian. Hal ini berarti penyebab kepercayaan pada online marketplace bukanlah berasal dari review dan rating namun dari hal lain. Hal ini dimungkinkan karena online marketplace telah memakai rekening bersama dan merupakan sebuah perusahaan besar dan juga beberapa memiliki garansi ketika berbelanja.

Karena pentingnya review dan rating, online marketplace harus menggunakan review dan rating sebagai salah satu tools marketing utama, caranya dengan meningkatkan penggunaan dan pemberian dari review dan rating tersebut. Selain itu online marketplace juga perlu untuk meningkatkan kepercayaan terhadap perusahaan dengan cara meningkatkan kredibilitas dari penjual yang berada disana. 


\section{UCAPAN TERIMA KASIH}

Penulis A.F. mengucapkan terima kasih kepada orang tua yang telah memberikan kesempatan untuk dapat menimba ilmu hingga jenjang ini dan juga atas bantuan yang telah mereka berikan baik moril maupun materil. Selain itu juga diucapkan terima kasih kepada kedua dosen Pembimbing yang telah membantu menyelesaikan penelitian ini hingga akhir. Terakhir kepada teman-teman yang selalu membantu dan juga pihakpihak lain yang membantu tanpa bisa disebutkan satu persatu.

\section{DAFTAR PUSTAKA}

[1] Kotler, P., \& Keller, K. L. (2012). Marketing management. Upper Saddle River, N.J: Pearson Prentice Hall.

[2] Kim, D. J., Ferrin, D. L., \& Rao, H. R. (2008). A trust-based consumer decision-making model in electronic commerce: the role of trust, perceived risk, and their antecedents. Decision Support Systems, 44(2)

[3] Sia, K. S., Lim, K. H., Leung, K., Lee, M. K. O. and Huang, W. W. (2009). Web strategies to promote Internet shopping: Is culturalcustomization needed? MIS Quarterly, 33(3), 419-512.

[4] Chiu, C. M., Hsu, M. H., Lai, H., \& Chang, C. M. (2012). Re-examining the influence of trust on online repeat purchase intention: The moderating role of habit and its antecedents. Decision Support Systems, 53(4), 835845.

[5] Hu, N., Pavlou, P. A., \& Zhang, J. (2006). Can online reviews reveal a product's true quality?: Empirical findings and analytical modeling of online word-of-mouth communication. In J. Feigenbaum, J. Chuang, \& D.M. Pennock (Eds.), Proceedings of the 7th ACM conference on electronic commerce (pp. 324-330). ACM

[6] Huang, P., Lurie, N. H., \& Mitra, S. (2009). Searching for experience on the web: An empirical examination of consumer behavior for search and experience goods. Journal of Marketing, 73, 55-69.

[7] Mudambi, S. M., \& Schuff, D. (2010). What makes a helpful review? A study of customer reviews on Amazon. com. MIS quarterly, 34(1), 185200.

[8] Chaffey, D., \& Smith, P. R. (2013). Emarketing Exellence. Planning and optimizing your digital marketing. Abingdon: Routledge.

[9] Bakos, J. Y. (1991). A strategic analysis of electronic marketplaces. MIS quarterly, 295-310.

[10] Lee, E.-J. \& Shin, S.Y. (2014). When do consumers buy online product reviews? Effects of review quality, product type, and reviewer's photo. Computers in Human Behavior, 31, 356-366.

[11] Li, N. and Zhang, P. (2002), "Consumer online shopping attitudes and behavior: an assessment of research.

[12] Moe, W.W., Schweidel, D.A. (2012). Online product opinions: incidence, evaluation, and evolution. Mark. Sci. 31 (3), 372-386

[13] Davis, F. D. (1989). Perceived usefulness, perceived ease of use, and user acceptance of information technology. MIS Quarterly, 13(3), 319-340.

[14] Elwalda, A., Lü, K., \& Ali, M. (2016). Perceived derived attributes of online customer reviews. Computers in Human Behavior, 56, 306-319.

[15] Ajzen, I. (1988). Attitudes, personality, and behavior. Chicago: Dorsey Press.

[16] Ajzen, I. (1991). The theory of planned behavior. Organizational Behavior and Human Decision Processes, 50(2), 179-211.

[17] Ajzen, I. (1985). From intentions to actions: a theory of planned behavior. In Action control: From cognition to behavior (pp. 11-39). Springer Berlin Heidelberg.

[18] Hermawan, A. (2006). Penelitian Bisnis Paradigma Kuantitatif. Jakarta: Gramedia Widiasarana Indonesia.

[19] Malhotra, N. K., \& Peterson, M. (2009). Basic marketing research: A decision-making approach. Prentice hall.

[20] Hair, J. F., Black, W. C., Babin, B. J., \& Anderson, R. E. (2014). Exploratory factor analysis. Multivariate data analysis, 7th Pearson new international ed. Harlow: Pearson.

[21] Malhotra, K., \& Birks, D. (2007). Marketing Research: An Applied Approach.3rd European Edition. Edinburgh: Pearson Education.
[22] Tsang, A. S., \& Prendergast, G. (2009). Is a "star" worth a thousand words? The interplay between product-review texts and rating valences. European Journal of Marketing, 43(11/12), 1269-1280. 